\title{
Constituents of Roots of Salvia deserta Schang. (Xinjiang-Danshen)
}

\author{
Yasuhiro TezuKa, ${ }^{a}$ Rena Kasimu, ${ }^{a}$ Jian Xin Li,${ }^{a}$ Purusotam Basnet,${ }^{a}$ Ken Tanaka, ${ }^{b}$ \\ Tsuneo NAmbA, ${ }^{a}$ and Shigetoshi Kadota ${ }^{*, a}$
}

Research Institute for Wakan-Yaku (Traditional Sino-Japanese Medicines), ${ }^{a}$ Toyama Medical and Pharmaceutical University, 2630 Sugitani, Toyama 930-01, Japan and National Research Institute of Police Science, ${ }^{b} 6$ Sanban-cho, Chiyoda-Ku, Tokyo 102, Japan. Received July 14, 1997; accepted October 13, 1997

Salvia deserta Schang. (Lamiaceae) is a plant grown in Xinjiang province in China, and its dried roots are called Xinjiang-Danshen. This plant has not been used as a medicine or a food, but recently it was reported that Xinjiang-Danshen is mixed in Danshen (roots of $S$. miltiorhiza BUNGE), a well-known Chinese crude drug, at Xinjiang province when latter was in short supply. We examined the constituents of the roots of $S$. deserta (Xinjiang-Danshen) and identified a new caffeic acid trimer [salvianolic acid $K(1)$ ], along with two known caffeic acid dimers [salviaflaside (2), rosmarinic acid (3)], a known caffeic acid tetramer [lithospermic acid B (4)], seven known abietane-type diterpenes [6,7-dehydroroyleanone (5), royleanone (6), taxodione (7), ferruginol (8), 7-O-methylhorminone (9), 7- $O$-acetylhorminone (10), horminone (11)], and a known steroid [daucosterol (12)].

Five of the diterpenes $(5,6,9-11)$ were "royleanones" and the main caffeic acid derivative was the trimer 1. These differed from the constituents of roots of $S$. miltiorhiza, which contains "tanshinones" as diterpenes and magnesium lithospermate $B$ as the main caffeic acid derivative. Thus, the mixing of Xinjiang-Danshen with Danshen is not appropriate and two should be considered different drugs.

Key words Xinjiang-Danshen; Salvia deserta; Lamiaceae; salvianolic acid K; salviaflaside; royleanones

Salvia deserta Schang. (Lamiaceae) is a plant grown in Xinjiang province in China, ${ }^{1)}$ and its dried roots are called Xinjiang-Danshen (新疆丹参). This plant has not been used as a medicine or a food, but recently it was reported that Xinjiang-Danshen is mixed in Danshen (丹参, roots of $S$. miltiorhiza BunGE), a well-known Chinese crude drug,${ }^{2)}$ at Xinjiang province when the latter was in short supply. ${ }^{3)}$ Many papers have been made on the constituents and/or biological activities of roots of $S$. miltiorhiza (Danshen) ${ }^{4,5)}$ and we also reported its aldose reductase inhibitory constituents ${ }^{6}$ and hepatoprotective action of its constituent, magnesium lithospermate B. ${ }^{7)}$ On constituents of $S$. deserta, however, there are only three reports: one stating that there are eight triterpenes in leaves, ${ }^{8)}$ one reporting detection of "royleanones"9) in roots by $\mathrm{TLC},{ }^{10)}$ and one reporting detection of 7-Oacetylhorminone and horminone in roots. ${ }^{11)}$ In our continuous study on Salvia plants, we also examined the constituents of the roots of $S$. deserta and identified a new compound called salvianolic acid K (1), along with eleven known ones (2-12). In this paper, we report their isolation and structure elucidation.

\section{Results and Discussion}

Constituents of AcOEt-Soluble Fraction The AcOEtsoluble fraction of the $\mathrm{MeOH}$ extract of roots of $S$. deserta was separated with a combination of silica gel column and normal-phase preparative TLC to yield eight nonpolar compounds (5-12). Their structures were determined by analyses of the ${ }^{1} \mathrm{H}-{ }^{1} \mathrm{H}$ shift correlation
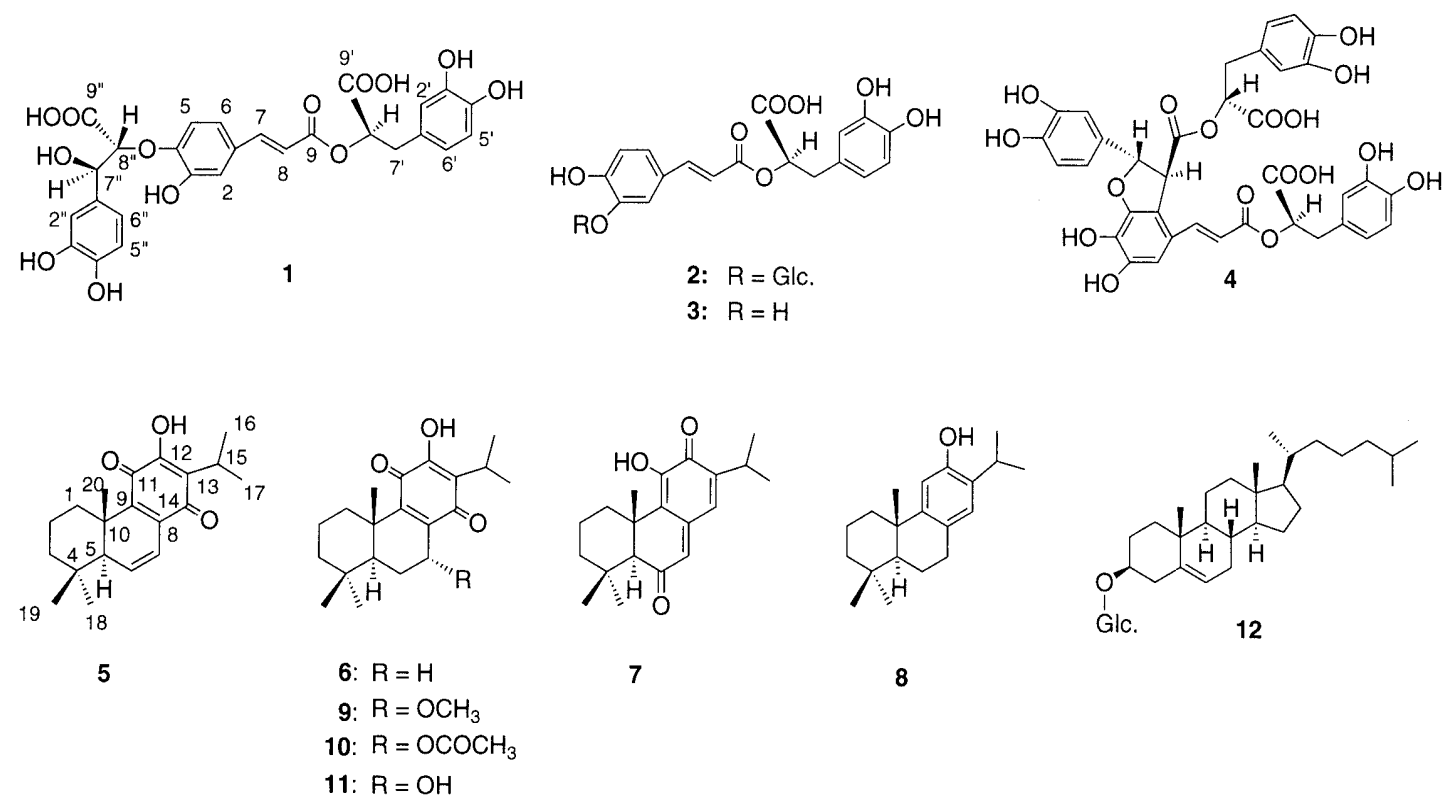

7

8

Chart 1 
Table 1. ${ }^{1} \mathrm{H}-\mathrm{NMR}$ Data $(\delta, J$ in $\mathrm{Hz})$ for Diterpenes $5-\mathbf{1 1}$ in $\mathrm{CDCl}_{3}$

\begin{tabular}{|c|c|c|c|c|c|c|c|}
\hline & $5^{a)}$ & $6^{b)}$ & $9^{b)}$ & $10^{b)}$ & $11^{b)}$ & $7^{c)}$ & $8^{a)}$ \\
\hline \multirow[t]{2}{*}{1} & $\begin{array}{l}1.43 \mathrm{td} \\
\quad(13.5,4)\end{array}$ & $\begin{array}{l}1.12 \mathrm{td} \\
\quad(13.5,3.5)\end{array}$ & $\begin{array}{l}1.19 \mathrm{td} \\
\quad(13.5,3.5)\end{array}$ & $\begin{array}{l}1.22 \mathrm{td} \\
\quad(13.5,3.5)\end{array}$ & $\begin{array}{l}1.18 \mathrm{td} \\
\quad(13.5,3.5)\end{array}$ & $2.94 \mathrm{~m}$ & $\begin{array}{l}1.37 \mathrm{td} \\
\quad(13.5,3.5)\end{array}$ \\
\hline & $\begin{array}{l}2.89 \mathrm{dt} \\
\quad(13.5,4)\end{array}$ & $\begin{array}{l}2.75 \mathrm{dtd} \\
\quad(13.5,3.5,1.5)\end{array}$ & $\begin{array}{l}2.68 \mathrm{brdt} \\
\quad(13.5,3.5)\end{array}$ & $\begin{array}{l}2.73 \mathrm{dtd} \\
\quad(13.5,3.5,1.5)\end{array}$ & $\begin{array}{l}2.70 \mathrm{dtd} \\
\quad(13.5,3.5,1.5)\end{array}$ & $1.75 \mathrm{~m}$ & $\begin{array}{l}2.15 \mathrm{dtd} \\
\quad(13.5,3.5,1.5)\end{array}$ \\
\hline \multirow[t]{2}{*}{2} & $\begin{array}{l}1.61 \mathrm{dq}^{d)} \\
\quad(13.5,4)\end{array}$ & $\begin{array}{l}1.53 \mathrm{dq}^{d)} \\
\quad(13.5,3.5)\end{array}$ & $\begin{array}{l}1.54 \mathrm{dq}^{d)} \\
\quad(13.5,3.5)\end{array}$ & $\begin{array}{l}1.57 \mathrm{dq}^{\mathrm{d}\rangle} \\
\quad(13.5,3.5)\end{array}$ & $\begin{array}{l}1.47 \mathrm{dtd} \\
\quad(13.5,3.5,1.5)\end{array}$ & $\begin{array}{l}1.59 \mathrm{dq}^{d)} \\
\quad(13.5,3.5)\end{array}$ & $\begin{array}{l}1.58 \mathrm{dq}^{d)} \\
\quad(13.5,3.5)\end{array}$ \\
\hline & $\begin{array}{l}1.70 \mathrm{qt} \\
(13.5,4)\end{array}$ & $\begin{array}{l}1.72 \mathrm{qt} \\
(13.5,3.5)\end{array}$ & $\begin{array}{l}1.73 \mathrm{qt} \\
(13.5,3.5)\end{array}$ & $\begin{array}{l}1.75 \mathrm{qt} \\
\quad(13.5,3.5)\end{array}$ & $\begin{array}{l}1.73 \mathrm{qt} \\
(13.5,3.5)\end{array}$ & $\begin{array}{l}1.71 \mathrm{qt} \\
(13.5,3.5)\end{array}$ & $\begin{array}{l}1.72 \mathrm{qt} \\
(13.5,3.5)\end{array}$ \\
\hline \multirow[t]{2}{*}{3} & $1.24 \mathrm{~m}$ & $1.20 \mathrm{~m}$ & $\begin{array}{l}1.24 \mathrm{td} \\
\quad(13.5,3.5)\end{array}$ & $\begin{array}{l}1.23 \mathrm{td} \\
\quad(13.5,3.5)\end{array}$ & $\begin{array}{l}1.25 \mathrm{dt} \\
(13.5,3.5)\end{array}$ & $1.20 \mathrm{~m}$ & $\begin{array}{l}1.23 \mathrm{td} \\
\quad(13.5,3.5)\end{array}$ \\
\hline & $\begin{array}{l}1.49 \mathrm{dt} \\
\quad(13.5,4)\end{array}$ & $\begin{array}{l}1.46 \mathrm{dtd} \\
\quad(13.5,3.5,1.5)\end{array}$ & $\begin{array}{l}1.47 \mathrm{dtd} \\
\quad(13.5,3.5,1.5)\end{array}$ & $\begin{array}{l}1.49 \mathrm{dtd} \\
\quad(13.5,3.5,1.5)\end{array}$ & $\begin{array}{l}1.56 \mathrm{dt} \\
(13.5,3.5)\end{array}$ & $\begin{array}{l}1.41 \mathrm{dtd} \\
\quad(13.5,3.5,1.5)\end{array}$ & $\begin{array}{l}1.46 \mathrm{dtd} \\
\quad(13.5,3.5,1.5)\end{array}$ \\
\hline 5 & $2.14 \mathrm{t}(3)$ & $1.10 \mathrm{dd}(12.5,1.5)$ & $1.57 \mathrm{dd}(13,1.5)$ & $1.48 \mathrm{dd}(13,1.5)$ & $1.54 \operatorname{brd}(13.5)$ & $2.60 \mathrm{~s}$ & $1.31 \mathrm{dd}(12.5,2)$ \\
\hline \multirow[t]{2}{*}{6} & $\begin{array}{l}6.47 \mathrm{dd} \\
\quad(10,3)\end{array}$ & $\begin{array}{l}1.38 \text { dddd } \\
\text { (13.5, 12.5, 11.5, } \\
6)\end{array}$ & $\begin{array}{l}1.35 \text { ddd } \\
(14,13,3.5)\end{array}$ & $\begin{array}{l}1.61 \mathrm{ddd} \\
\quad(14.5,13,4)\end{array}$ & $\begin{array}{l}1.61 \mathrm{td} \\
\quad(13.5,4.5)\end{array}$ & & $\begin{array}{l}1.66 \text { dddd } \\
\quad(13.5,12.5,11,7)\end{array}$ \\
\hline & & $\begin{array}{l}1.87 \mathrm{ddt} \\
\quad(13.5,7.5,1.5)\end{array}$ & $\begin{array}{l}2.04 \mathrm{dt} \\
\quad(14,1.5)\end{array}$ & $\begin{array}{l}1.95 \mathrm{dt} \\
\quad(14.5,1.5)\end{array}$ & $\begin{array}{c}1.97 \mathrm{brd} \\
(13.5)\end{array}$ & & $\begin{array}{l}1.85 \mathrm{ddt} \\
\quad(13.5,7.5,2)\end{array}$ \\
\hline 7 & $\begin{array}{l}6.81 \mathrm{dd} \\
\quad(10,3)\end{array}$ & $\begin{array}{l}2.34 \text { ddd } \\
\quad(21,11.5,7.5) \\
2.71 \mathrm{ddd} \\
\quad(21,6,1.5)\end{array}$ & $\begin{array}{l}4.32 \mathrm{dd} \\
\quad(3.5,1.5)\end{array}$ & $\begin{array}{l}5.94 \mathrm{dd} \\
\quad(4,1.5)\end{array}$ & $\begin{array}{l}4.73 \mathrm{brd} \\
(4.5)\end{array}$ & $6.21 \mathrm{~s}$ & $\begin{array}{l}2.76 \mathrm{ddd} \\
(16.5,11,7.5) \\
2.85 \mathrm{ddd} \\
(16.5,7,2)\end{array}$ \\
\hline 11 & & & & & & & $6.61 \mathrm{~s}$ \\
\hline 14 & & & & & & $6.88 \mathrm{~s}$ & $6.81 \mathrm{~s}$ \\
\hline 15 & 3.17 heptet $(7)$ & 3.15 heptet $(7)$ & 3.18 heptet (7) & 3.16 heptet (7) & 3.16 heptet (7) & 3.07 heptet $(7)$ & 3.11 heptet (7) \\
\hline 16 & $1.22 \mathrm{~d}(7)$ & $1.20 \mathrm{~d}(7)$ & $1.20 \mathrm{~d}(7)$ & $1.19 \mathrm{~d}(7)$ & $1.21 \mathrm{~d}(7)$ & $1.18 \mathrm{~d}(7)$ & $1.22 \mathrm{~d}(7)$ \\
\hline 17 & $1.23 \mathrm{~d}(7)$ & $1.21 \mathrm{~d}(7)$ & $1.23 \mathrm{~d}(7)$ & $1.23 \mathrm{~d}(7)$ & $1.22 \mathrm{~d}(7)$ & $1.16 \mathrm{~d}(7)$ & $1.24 \mathrm{~d}(7)$ \\
\hline 18 & $0.98 \mathrm{~s}$ & $0.93 \mathrm{~s}$ & $0.95 \mathrm{~s}$ & $0.89 \mathrm{~s}$ & $0.98 \mathrm{~s}$ & $1.12 \mathrm{~s}$ & $0.93 \mathrm{~s}$ \\
\hline 19 & $1.02 \mathrm{~s}$ & $0.90 \mathrm{~s}$ & $0.91 \mathrm{~s}$ & $0.88 \mathrm{~s}$ & $0.90 \mathrm{~s}$ & $1.27 \mathrm{~s}$ & $0.91 \mathrm{~s}$ \\
\hline 20 & $1.04 \mathrm{~s}$ & $1.25 \mathrm{~s}$ & $1.22 \mathrm{~s}$ & $1.24 \mathrm{~s}$ & $1.21 \mathrm{~s}$ & $1.27 \mathrm{~s}$ & $1.16 \mathrm{~s}$ \\
\hline Others & $7.36 \mathrm{~s}(12-\mathrm{OH})$ & $7.23 \mathrm{~s}(12-\mathrm{OH})$ & $\begin{array}{l}3.45 \mathrm{~s}\left(\mathrm{OCH}_{3}\right) \\
7.12 \mathrm{~s}(12-\mathrm{OH})\end{array}$ & $\begin{array}{l}2.03 \mathrm{~s}\left(\mathrm{COCH}_{3}\right) \\
7.18 \mathrm{brs}(12-\mathrm{OH})\end{array}$ & $\begin{array}{l}3.07 \text { br s }(7-\mathrm{OH}) \\
7.33 \text { br s }(12-\mathrm{OH})\end{array}$ & $7.57 \mathrm{~s}(11-\mathrm{OH})$ & $4.60 \mathrm{brs}(12-\mathrm{OH})$ \\
\hline
\end{tabular}

a) Assigned by the ${ }^{1} \mathrm{H}-{ }^{1} \mathrm{H},{ }^{1} \mathrm{H}-{ }^{13} \mathrm{C}$, and long-range ${ }^{1} \mathrm{H}-{ }^{13} \mathrm{C}$ COSY spectra. b) Assigned by the ${ }^{1} \mathrm{H}^{1} \mathrm{H}^{2}$ and ${ }^{1} \mathrm{H}-{ }^{13} \mathrm{C}$ COSY spectra. c) Assigned by the ${ }^{1} \mathrm{H}-{ }^{1} \mathrm{H}$ COSY, HMQC, and HMBC spectra. d) Quintet.

spectroscopy (COSY) spectrum, ${ }^{1} \mathrm{H}^{-13} \mathrm{C}$ COSY or ${ }^{1} \mathrm{H}$-detected heteronuclear multiple-quantum correlation (HMQC) spectrum, and long-range ${ }^{1} \mathrm{H}^{-13} \mathrm{C}$ COSY or ${ }^{1} \mathrm{H}$-detected heteronuclear multiple-bond multiple-quantum correlation (HMBC) spectrum, and comparison with the literature data showed them to be 6,7-dehydroroyleanone $^{12,13)}(5)$, royleanone ${ }^{12,14)}(6)$, taxodione ${ }^{15)}(7)$, ferruginol $^{16)}(\mathbf{8}), 7-O$-methylhorminone ${ }^{17)}(9), 7-O$-acetylhorminone $^{12)}(\mathbf{1 0})$, horminone ${ }^{12,13,17)}(\mathbf{1 1})$, and daucosterol $^{18)}$ (12). Analyses of the two-dimensional (2D) NMR spectra also gave the unambiguous assignments of their ${ }^{1} \mathrm{H}$ - and ${ }^{13} \mathrm{C}$-signals and led to the revision of some previous ${ }^{13} \mathrm{C}$-assignments (Tables 1,2 ).

Constituents of AcOEt-Insoluble Fraction and Structure of Salvianolic Acid K (1) The AcOEt-insoluble fraction of the $\mathrm{MeOH}$ extract was separated by a combination of Sephadex LH-20 column chromatography and reversedphase preparative TLC to give a new caffeic acid trimer, salvianolic acid K (1), two known dimers, salviaflaside ${ }^{19)}$ (2) and rosmarinic $\operatorname{acid}^{20)}(\mathbf{3})$, and a known tetramer, lithospermic acid $\mathrm{B}^{7,21)}(\mathbf{4})$.

Salvianolic acid K (1) was obtained as a colorless amorphous solid, having $[\alpha]_{\mathrm{D}}^{26}+31.2^{\circ}\left(\mathrm{H}_{2} \mathrm{O}\right)$, and its molecular formula was determined by high-resolution negative ion FAB-MS to be $\mathrm{C}_{27} \mathrm{H}_{24} \mathrm{O}_{13}(\mathrm{~m} / z$ 556), corresponding to caffeic acid trimer. The ${ }^{1} \mathrm{H}-$ and ${ }^{13} \mathrm{C}$ NMR spectra of $\mathbf{1}$ were partially similar to those of $\mathbf{2}$
Table 2. ${ }^{13} \mathrm{C}$-NMR Data $(\delta)$ for Diterpenes $5-11$ in $\mathrm{CDCl}_{3}$

\begin{tabular}{cccccccc}
\hline \hline & $\mathbf{5}^{a)}$ & $\mathbf{6}^{b)}$ & $\mathbf{9}^{b)}$ & $\mathbf{1 0}^{b)}$ & $\mathbf{1 1}^{b)}$ & $\mathbf{7}^{(\mathbf{)}}$ & $\mathbf{8}^{(\mathbf{)}}$ \\
\hline 1 & 35.2 & 36.2 & 35.8 & 35.8 & 35.8 & 37.1 & 38.9 \\
2 & 18.7 & 18.9 & 18.9 & 18.8 & 18.9 & 18.6 & 19.4 \\
3 & 40.5 & 41.3 & 41.0 & 41.0 & 41.1 & 42.6 & 41.8 \\
4 & 33.3 & 33.4 & $33.1^{d)}$ & 33.0 & $33.0^{d)}$ & 32.9 & 33.5 \\
5 & 52.1 & 51.7 & 45.5 & 46.1 & 45.7 & 63.1 & 50.4 \\
6 & $139.6^{d)}$ & 17.4 & 22.2 & 24.6 & 25.8 & 201.0 & 19.3 \\
7 & $121.1^{d)}$ & 26.7 & 70.8 & 64.5 & 63.2 & 134.0 & 29.8 \\
8 & 138.5 & 146.0 & 141.5 & 139.4 & 143.2 & 140.0 & 127.3 \\
9 & 140.5 & 146.5 & 147.9 & 150.0 & 147.8 & 125.7 & 148.7 \\
10 & 39.3 & 38.4 & $39.2^{d)}$ & 39.1 & $39.1^{d)}$ & 42.9 & 37.5 \\
11 & 183.5 & 183.4 & 184.2 & 183.7 & 183.9 & $145.0^{d)}$ & 111.0 \\
12 & 151.2 & 150.5 & 150.6 & 150.8 & 151.1 & 181.7 & 150.7 \\
13 & 122.6 & 123.7 & 124.8 & 124.7 & 124.2 & $145.4^{d)}$ & 131.4 \\
14 & 186.0 & 187.5 & 186.4 & 185.4 & 189.1 & 136.2 & 126.6 \\
15 & $24.1^{d)}$ & 24.1 & 24.3 & 24.1 & 24.0 & 27.2 & 26.8 \\
16 & $19.8^{e)}$ & $19.9^{e)}$ & $19.7^{e)}$ & $19.7^{e)}$ & $19.8^{e)}$ & $21.3^{e)}$ & $22.6^{e)}$ \\
17 & $20.0^{e)}$ & $20.0^{e)}$ & $19.9^{e)}$ & $19.9^{e)}$ & $19.9^{e)}$ & $21.6^{())}$ & $22.8^{e)}$ \\
18 & 32.6 & 33.5 & 33.1 & 33.0 & 33.1 & 33.3 & 33.3 \\
19 & $22.8^{d)}$ & 21.8 & 21.9 & 21.6 & 21.7 & $22.1^{\text {d) }}$ & 21.7 \\
20 & 15.2 & 20.0 & 18.6 & 18.5 & 18.4 & $21.9^{d)}$ & 24.8 \\
$\mathrm{COCH}_{3}$ & & & & 21.1 & & & \\
$\mathrm{COCH}_{3}$ & & & & 169.4 & & & \\
$\mathrm{OCH}_{3}$ & & & 57.3 & & & & \\
& & & & & & &
\end{tabular}

a) Assigned by the ${ }^{1} \mathrm{H}-{ }^{1} \mathrm{H}, \quad{ }^{1} \mathrm{H}^{13} \mathrm{C}$, and long-range ${ }^{1} \mathrm{H}^{-13} \mathrm{C} \quad \mathrm{COSY}$ spectra. b) Assigned by the ${ }^{1} \mathrm{H}-{ }^{1} \mathrm{H}$ and ${ }^{1} \mathrm{H}^{13}{ }^{13} \mathrm{C}$ COSY spectra. c) Assigned by the ${ }^{1} \mathrm{H}-{ }^{1} \mathrm{H}$ COSY, HMQC, and HMBC spectra. d) Previous assignments have been revised. e) Assignments may be interchanged in each column. 
and 3 and showed the signals due to three sets of 1,3,4trisubstituted aromatic ring, a trans-olefin, a (O)$\mathrm{CH}-\mathrm{CH}-(\mathrm{O})$ grouping, and a $\mathrm{CH}_{2}-\mathrm{CH}-(\mathrm{O})$ grouping (Table 3).

The planar structure of $\mathbf{1}$ was elucidated by analyses of the ${ }^{1} \mathrm{H}-{ }^{1} \mathrm{H}$ and ${ }^{1} \mathrm{H}-{ }^{13} \mathrm{C}$ COSY and HMBC spectra. In the HMBC spectrum (Chart 2), long-range correlations were observed between the benzylic protons/carbons and the aromatic carbons/protons at the corresponding orthopositions; 7-H/C-2,C-6, 7'-H $2 / \mathrm{C}-2^{\prime}, \mathrm{C}-6^{\prime}, 7^{\prime \prime}-\mathrm{H} / \mathrm{C}-2^{\prime \prime}, \mathrm{C}-6^{\prime \prime}$, $2-\mathrm{H} / \mathrm{C}-7,2^{\prime}-\mathrm{H} / \mathrm{C}-7^{\prime}$, and $2^{\prime \prime}-\mathrm{H}, 6^{\prime \prime}-\mathrm{H} / \mathrm{C}-7^{\prime \prime}$. The spectrum

Table 3. ${ }^{1} \mathrm{H}$ - and ${ }^{13} \mathrm{C}-\mathrm{NMR}$ Data for Compounds $1-3$ in DMSO- $d_{6}$

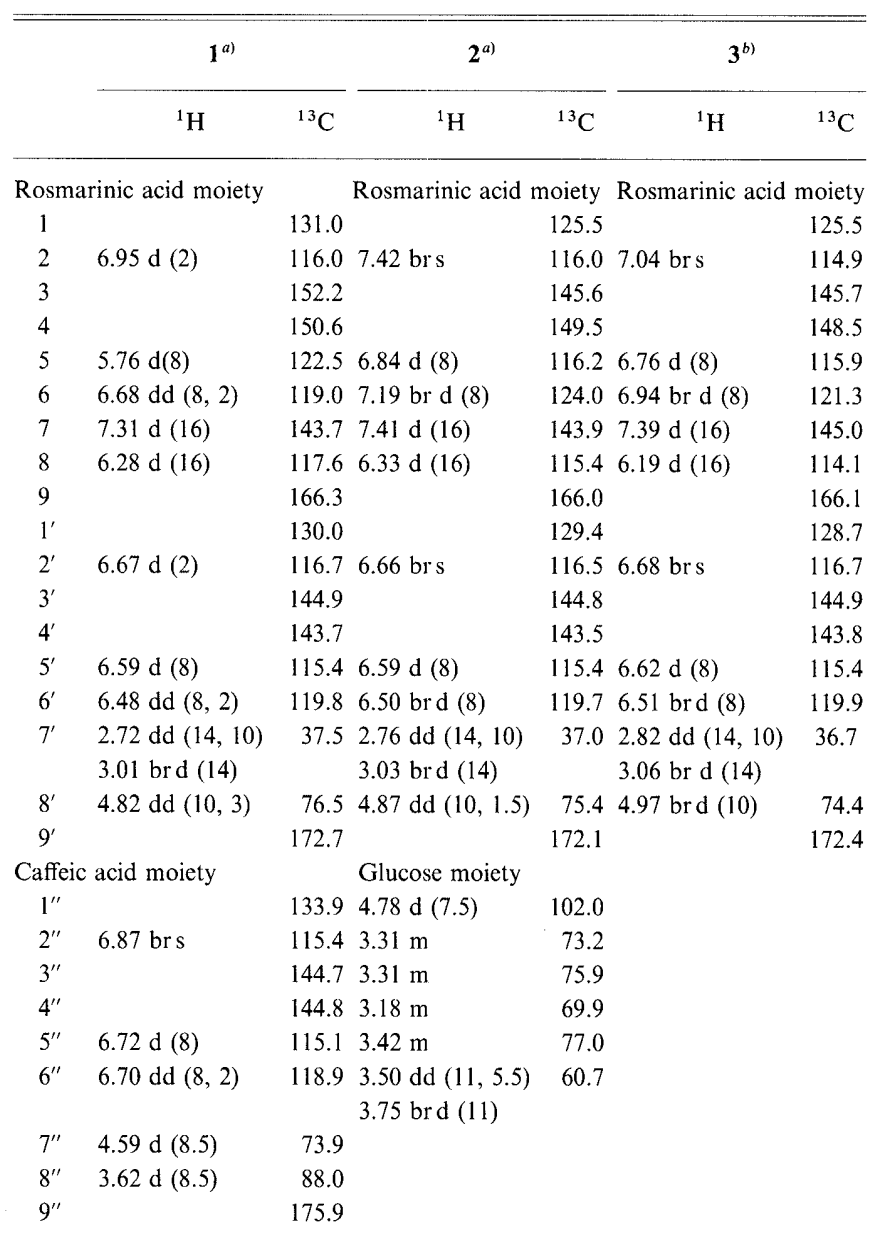

a) Assigned by the ${ }^{1} \mathrm{H}-{ }^{-1} \mathrm{H}$ and ${ }^{1} \mathrm{H}-{ }^{13} \mathrm{C}$ COSY and $\mathrm{HMBC}$ spectra. b) Assigned by the ${ }^{1} \mathrm{H}-{ }^{1} \mathrm{H}$ and ${ }^{1} \mathrm{H}-{ }^{13} \mathrm{C}$ COSY spectra and comparison with the data for $\mathbf{1}$ and $\mathbf{2}$. also showed the correlations between the ester carbonyl carbon and the protons, $\mathrm{C}-9 / 7-\mathrm{H}, 8-\mathrm{H}, 8^{\prime}-\mathrm{H}$. These and other long-range correlations depicted in Chart 2 by arrows indicated the presence of rosmarinic acid and 2,3-dihydroxy-3-(3,4-dihydroxyphenyl)propionic acid moieties. In addition, based on the long-range correlation between $8^{\prime \prime}-\mathrm{H}$ and $\mathrm{C}-4$, the latter moiety was determined to locate at the C-4 position of the former. From these and other long-range correlations, the planer structure of 1 was determined, except for the stereochemistry.

The stereochemistry at C-8', C-7", and C-8", including the absolute one, was elucidated through the NMR and chemical studies (Chart 3). Salvianolic acid K (1) was methylated with $\left(\mathrm{CH}_{3}\right)_{2} \mathrm{SO}_{4}-\mathrm{K}_{2} \mathrm{CO}_{3}$ to give a heptamethylsalvianolic acid $\mathrm{K}(\mathbf{1 a}) ; \delta_{\mathrm{H}} 3.70,3.75,3.85,3.86$, $3.87(6 \mathrm{H}), 3.89 ; m / z 655.2396[\mathrm{M}+\mathrm{H}]^{+}\left(\mathrm{C}_{34} \mathrm{H}_{39} \mathrm{O}_{13}\right)$, which was then reduced with diisobutylaluminum hydride (DIBAH) to give an 8-O-4' neolignan 13 (Chart 3). Hattori et al. ${ }^{22)}$ reported that the threo and erythro diastereomers of $8-O-4^{\prime}$ lignans give the large $(8.0-8.6 \mathrm{~Hz})$ and small $(2.7-4.4 \mathrm{~Hz}) J$ values for $7-\mathrm{H}$ and $8-\mathrm{H}$, while Braga et $a .^{23)}$ and Matsuda and Kikuchi ${ }^{24)}$ reported that those of 8-O-4' neolignans correspond to the possible staggered conformers with intramolecular hydrogen bonding of the benzylic hydroxyl and aryloxyl groups. The 7"'-H and 8"-H of 13 showed the small $J$ values $(4.5 \mathrm{~Hz})$, indicating 13 (i.e., 1) to be erythro.

The absolute configuration of 1 was deduced by the Mosher method on the $(R)-(+)-\alpha$-methoxy- $\alpha$-trifluoromethylphenylacetyl (MTPA) ester (1b) and $(S)-(-)$ MTPA ester (1c) and chemical degradation. In the ${ }^{1} \mathrm{H}-\mathrm{NMR}$ spectrum of $\mathbf{1 b}, 2^{\prime \prime}-\mathrm{H}, 5^{\prime \prime}-\mathrm{H}$, and $6^{\prime \prime}-\mathrm{H}$ appeared upfield whereas $8 "-\mathrm{H}, 2-\mathrm{H}, 5-\mathrm{H}, 6-\mathrm{H}, 7-\mathrm{H}$ and $8-\mathrm{H}$ were downfield in comparison to those of $\mathbf{1 c}$, indicating that in the $R$-MTPA ester $2^{\prime \prime}-\mathrm{H}, 5^{\prime \prime}-\mathrm{H}$, and $6^{\prime \prime}-\mathrm{H}$ were affected by the phenyl ring of the MTPA part. ${ }^{25}$ ) The absolute configuration at C-7" was thus determined to be $R^{25,26)}$ (i.e., $\mathrm{C}-8$ " was $R$ ). By methanolysis with $\mathrm{NaOMe}-\mathrm{MeOH}$, on the other hand, the heptamethylate 1a gave methyl 3-(3,4-dimethoxyphenyl)-(2R)-propionate (14) and methyl 4-O-[(1S,2R)-2-hydroxy-1-methoxycarbonyl-2-(3,4-dimethoxyphenyl)ethyl]ferulate (15) along with two products via retro-aldole reaction, 3,4-dimethoxybenzaldehyde (16) and methyl 4-O-(methoxycarbonylmethyl)ferulate (17) (Chart 3). Based on the $[\alpha]_{D}$ value of $\mathbf{1 4}\left(-4.8^{\circ}\right.$, $\mathrm{MeOH}$; lit. $\left.{ }^{27)}-5.0^{\circ}, \mathrm{MeOH}\right)$, the absolute configuration

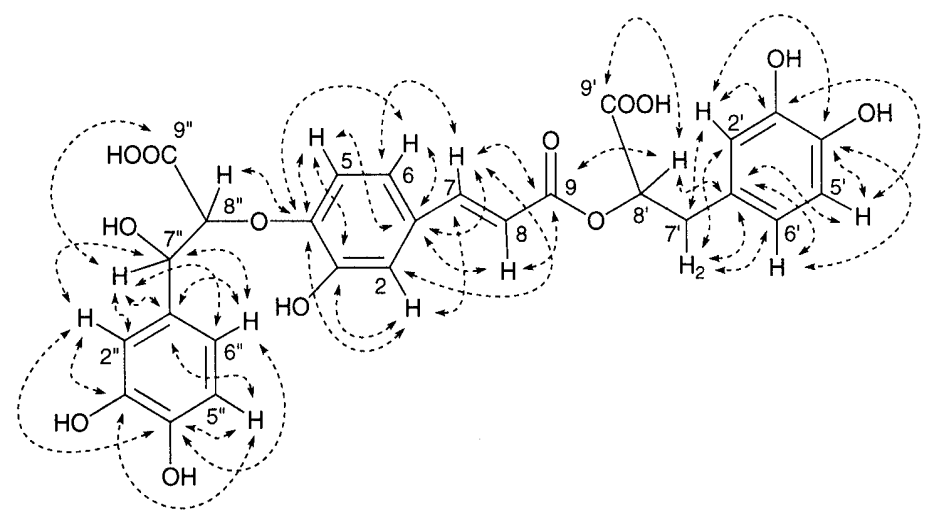

Chart 2. Significant Long-Range Correlations Observed in the Long-Range ${ }^{1} \mathrm{H}-{ }^{13} \mathrm{C}$ COSY and/or HMBC Spectra of 1 

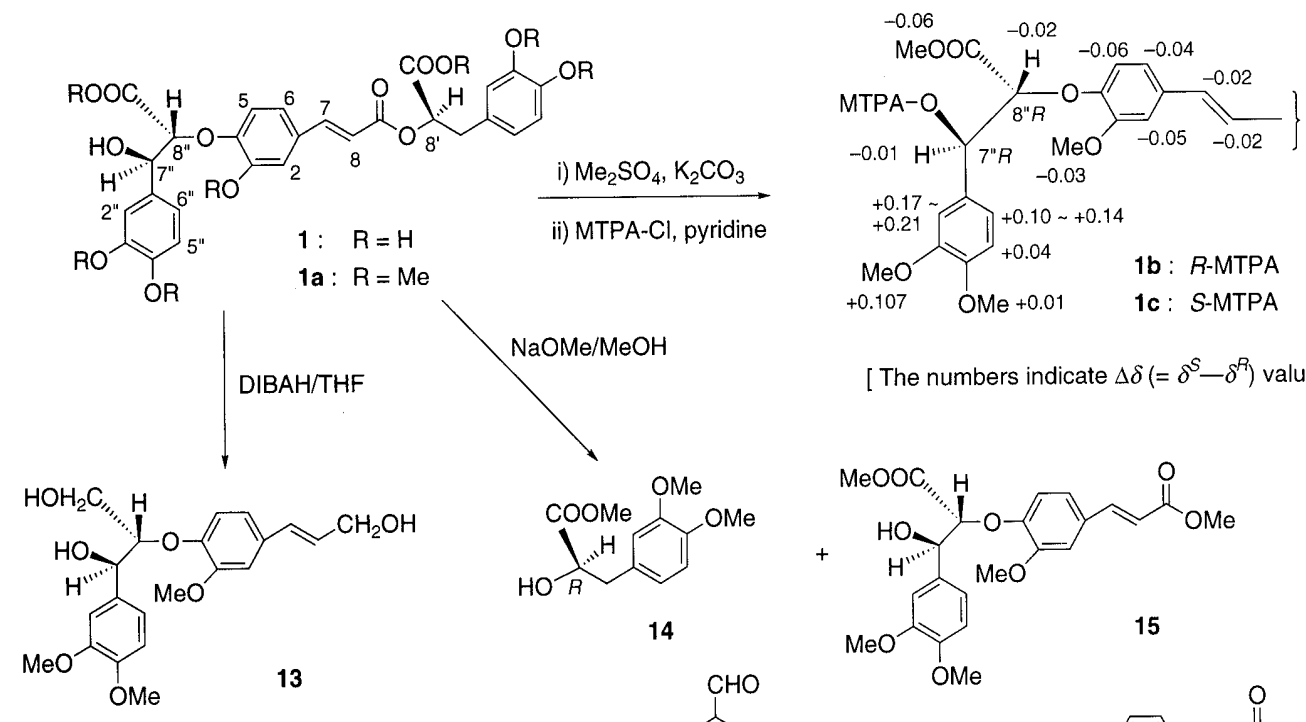

[ The numbers indicate $\Delta \delta\left(=\delta^{S}-\delta^{R}\right)$ values. ]
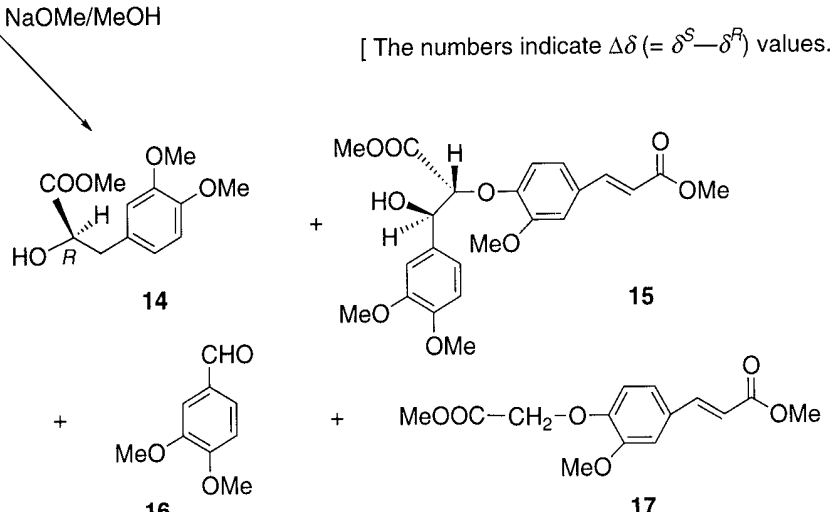

Chart 3

at $\mathrm{C}-8^{\prime}$ of $\mathbf{1 a}$ (i.e., 1) was determined to be $R$. Thus, salvianolic acid $\mathrm{K}$ was determined to be $\left(8^{\prime} R, 7^{\prime \prime} R, 8^{\prime \prime} R\right)-4-$ $O$-[1-carboxy-2-hydroxy-2-(3,4-dihydroxyphenyl)ethyl]rosmarinic acid (1).

\section{Conclusion}

Examination of the constituents of the roots of Salvia deserta SCHANG. (Xinjiang-Danshen, 新疆丹参) resulted in the isolation of one new [salvianolic acid $\mathrm{K}(1)$ ] and three known [salviaflaside (2), rosmarinic acid (3), lithospermic acid B (4)] caffeic acid derivatives, seven known abietane-type diterpenes [6,7-dehydroroyleanone (5), royleanone (6), taxodione (7), ferruginol (8), 7-O-methylhorminone (9), 7-O-acetylhorminone (10), horminone (11)], and a known steroid [daucosterol (12)]. Five of the diterpenes $(\mathbf{5}, \mathbf{6}, \mathbf{9 - 1 1})$ were "royleanones" and the main caffeic acid derivative was the trimer 1 . These differed from the constituents of roots of $S$. miltiorhiza BUNGE (Danshen, 丹参), which contains "tanshinones"9) (e.g., tanshinone I, tanshinone IIA, dihydrotanshinone I, and cryptotanshinone) as diterpenes and magnesium lithospermate $B$ as the main caffeic acid derivative. ${ }^{3-7,10,11)}$ Thus, the mixing of Xinjiang-Danshen to Danshen is not appropriate and the two should be considered different drugs.

\section{Experimental}

All melting points were determined with a Kofler-type apparatus and are uncorrected. Optical rotations were measured on a JASCO DIP-4 automatic polarimeter. IR spectra were taken on a Hitachi 260-10 IR spectrophotometer and UV spectra on a Shimadzu UV 2200 UV-visible spectrophotometer. NMR spectra were taken on a JEOL JNM-GX400 or a JNM-LA400 spectrometer with tetramethylsilane (TMS) as an internal standard. Electron impact mass spectra (EI-MS) were taken on a JEOL JMS-D300 mass spectrometer using a direct inlet system (ionization voltage, $70 \mathrm{eV}$; accelerating voltage, $3.0 \mathrm{kV}$ ), while FAB-MS and desorption chemical ionization mass spectra (DCI-MS) were measured with a JEOL JMS-700T mass spectrometer using glycerol as a matrix for FAB-MS and isobutane as a reaction gas for DCI-MS

Extraction and Fractionation Roots of $S$. deserta SCHANG. were collected at Urumqi in Xinjiang province in China in October of 1994. The raw material was identified by an expert and the voucher sample is preserved in the Museum for Materia and Medica, Analytical Research Center of Ethnopharmacology in our institute (TMPW No. 15403).

Chopped roots $(2 \mathrm{~kg})$ of $S$. deserta were extracted successively with water $\left(5 \mathrm{l}, 80^{\circ} \mathrm{C}, 3 \mathrm{~h}, \times 3\right)$ and $\mathrm{MeOH}(5 \mathrm{l}$, reflux, $3 \mathrm{~h}, \times 3)$, and were concentrated to give a water extract $(398 \mathrm{~g})$ and a $\mathrm{MeOH}$ extract $(92.6 \mathrm{~g})$, respectively. A part of the $\mathrm{MeOH}$ extract $(83.0 \mathrm{~g})$ was suspended in water and partitioned between AcOEt and water to give an AcOEt-soluble $(7.7 \mathrm{~g})$ and an AcOEt-insoluble $(70.5 \mathrm{~g})$ fraction.

Separation of the AcOEt-Soluble Fraction The AcOEt-soluble fraction $(5.0 \mathrm{~g})$ was subjected to silica gel column chromatography with a hexane- $\mathrm{CHCl}_{3}$ solvent system to give five fractions (fr. A, $10-20 \%$ $\mathrm{CHCl}_{3}$-hexane eluate, $0.12 \mathrm{~g}$; fr. $\mathrm{B}, 30-40 \% \mathrm{CHCl}_{3}$-hexane eluate, $0.05 \mathrm{~g}$; fr. C, $50-70 \% \mathrm{CHCl}_{3}$-hexane eluate, $0.16 \mathrm{~g}$; fr. D, $80-90 \%$ $\mathrm{CHCl}_{3}$-hexane eluate, $1.1 \mathrm{~g}$; fr. $\mathrm{E}, \mathrm{CHCl}_{3}$ eluate, $1.5 \mathrm{~g}$ ).

Fractions A $(40 \mathrm{mg}), B(50 \mathrm{mg}), \mathrm{C}(160 \mathrm{mg})$, and D $(1.1 \mathrm{~g})$ were respectively separated by normal-phase preparative TLC with AcOEthexane (1:99 for frs. A and D; 5:95 for frs. B and C). Fraction A gave 6,7-dehydroroyleanone ${ }^{12,13)}(\mathbf{5}, 10 \mathrm{mg})$, red needles, $\mathrm{mp} 148-153^{\circ} \mathrm{C}$ (from $\mathrm{MeOH}),[\alpha]_{\mathrm{D}}^{26}-586^{\circ}\left(\mathrm{CHCl}_{3}, c=0.09\right)$; fr. B gave royleanone ${ }^{12,14)}$ $\left(6,5 \mathrm{mg}\right.$ ), yellow needles, $\mathrm{mp} 178-180^{\circ} \mathrm{C}$ (from $\mathrm{MeOH}$ ), $[\alpha]_{\mathrm{D}}^{26}+129.6^{\circ}$ $\left(\mathrm{CHCl}_{3}, c=0.1\right)$, and taxodione ${ }^{15)}(7,3 \mathrm{mg})$, dark yellow amorphous solid, $[\alpha]_{\mathrm{D}}^{26}+38.9^{\circ}\left(\mathrm{CHCl}_{3}, c=0.1\right)$; fr. $\mathrm{C}$ gave ferruginol ${ }^{16)}(\mathbf{8}, 2 \mathrm{mg})$, yellow fine needles, $\mathrm{mp} 162-165^{\circ} \mathrm{C}$ (from $\mathrm{MeOH}$ ), $[\alpha]_{\mathrm{D}}^{26}+53.1^{\circ}$ $\left(\mathrm{CHCl}_{3}, c=0.09\right), 7-O$-methylhorminone ${ }^{17)}(9,5.5 \mathrm{mg})$, orange needles, $\mathrm{mp} 126-128^{\circ} \mathrm{C}$ (from $\left.\mathrm{MeOH}\right),[\alpha]_{\mathrm{D}}^{26}-44.0^{\circ}\left(\mathrm{CHCl}_{3}, c=0.05\right.$ ), and 7-O-acetylhorminone ${ }^{12)}(10,16 \mathrm{mg})$, yellow needles, $\mathrm{mp} 166-169^{\circ} \mathrm{C}$ (from $\mathrm{MeOH}),[\alpha]_{\mathrm{D}}^{26}-12.8^{\circ}\left(\mathrm{CHCl}_{3}, c=0.1\right)$; and fr. D gave $10(320 \mathrm{mg})$ and horminone ${ }^{12,13,17)}(\mathbf{1 1}, 410 \mathrm{mg})$, yellow crystals, $\mathrm{mp} 175-178^{\circ} \mathrm{C}$ (from $\mathrm{MeOH}),[\alpha]_{\mathrm{D}}^{26}-128.2^{\circ}\left(\mathrm{CHCl}_{3}, c=0.1\right)$. Fraction $\mathrm{E}(1.5 \mathrm{~g})$ gave daucosterol ${ }^{18)}(12,30 \mathrm{mg})$ by silica gel column chromatography with a $\mathrm{MeOH}-\mathrm{CHCl}_{3}$ solvent system.

Separation of the AcOEt-Insoluble Fraction The AcOEt-insoluble fraction $(70.5 \mathrm{~g})$ was separated by a MCI-gel CHP-20P column chromatography with a $\mathrm{MeOH}-\mathrm{H}_{2} \mathrm{O}$ solvent system into ten fractions (fr. $1, \mathrm{H}_{2} \mathrm{O}$ eluate, $29.3 \mathrm{~g}$; fr. $2,10-20 \% \mathrm{MeOH}-\mathrm{H}_{2} \mathrm{O}$ eluate, $5.0 \mathrm{~g}$; fr. $3,30 \% \mathrm{MeOH}-\mathrm{H}_{2} \mathrm{O}$ eluate, $2.0 \mathrm{~g}$; fr. $4,40 \% \mathrm{MeOH}-\mathrm{H}_{2} \mathrm{O}$ eluate, $1.7 \mathrm{~g}$; fr. $5,50 \% \mathrm{MeOH}-\mathrm{H}_{2} \mathrm{O}$ eluate, $0.8 \mathrm{~g}$; fr. $6,60 \% \mathrm{MeOH}-\mathrm{H}_{2} \mathrm{O}$ eluate, $0.7 \mathrm{~g}$; fr. $7,70 \% \mathrm{MeOH}-\mathrm{H}_{2} \mathrm{O}$ eluate, $1.9 \mathrm{~g}$; fr. $8,80 \% \mathrm{MeOH}-\mathrm{H}_{2} \mathrm{O}$ eluate, $0.6 \mathrm{~g}$; fr. $9,90 \% \mathrm{MeOH}-\mathrm{H}_{2} \mathrm{O}$ eluate, $0.6 \mathrm{~g}$; fr. 10 , $\mathrm{MeOH}$ eluate, $1.12 \mathrm{~g}$ ).

Fractions $2(4.8 \mathrm{~g})$ and $4(1.2 \mathrm{~g})$ were subjected to Sephadex LH-20 column chromatography with a $\mathrm{MeOH}-\mathrm{H}_{2} \mathrm{O}$ solvent system to give salvianolic acid $\mathrm{K}(1,2.64 \mathrm{~g})$ and rosmarinic acid ${ }^{20)}(3,540 \mathrm{mg})$, colorless amorphous solid, $[\alpha]_{\mathrm{D}}^{26}+48.5^{\circ}\left(\mathrm{H}_{2} \mathrm{O}, c=0.1\right)$, respectively.

Fraction $3(1.50 \mathrm{~g})$ was chromatographed over Sephadex LH-20 with 
a $\mathrm{MeOH}-\mathrm{H}_{2} \mathrm{O}$ solvent system to give five fractions (fr. 3-1, 20-30\% $\mathrm{MeOH}-\mathrm{H}_{2} \mathrm{O}$ eluate, $50 \mathrm{mg}$; fr. $3-2,40-50 \% \mathrm{MeOH}-\mathrm{H}_{2} \mathrm{O}$ eluate, 500 $\mathrm{mg}$; fr. $3-3,60-70 \% \mathrm{MeOH}-\mathrm{H}_{2} \mathrm{O}$ eluate, $230 \mathrm{mg}$; fr. 3-4, $80-90 \%$ $\mathrm{MeOH}-\mathrm{H}_{2} \mathrm{O}$ eluate, $260 \mathrm{mg}$; fr. 3-5, MeOH eluate, $30 \mathrm{mg}$ ). Fraction 3-2 $(40 \mathrm{mg}$ ) was separated by reversed-phase preparative TLC (RP-18 plate, $\left.\mathrm{CH}_{3} \mathrm{CN}: \mathrm{H}_{2} \mathrm{O}=23: 77\right)$ to give $3(7.3 \mathrm{mg})$, while fr. $3-3(230 \mathrm{mg})$ was subjected to re-chromatography with a Sephadex LH-20 column, followed by reversed-phase preparative TLC (RP-18 plate, $\mathrm{CH}_{3} \mathrm{CN}$ : $\left.\mathrm{H}_{2} \mathrm{O}=25: 75\right)$, to yield lithospermic acid $\mathrm{B}^{7,21)}(\mathbf{4}, 12 \mathrm{mg})$, colorless amorphous solid, $[\alpha]_{\mathrm{D}}^{26}+123.7^{\circ}\left(50 \% \mathrm{H}_{2} \mathrm{O}-\mathrm{MeOH}, c=0.1\right)$, and 3 $(15.6 \mathrm{mg})$. Similarly, fr. $3-4(260 \mathrm{mg})$ and fr. $3-5(30 \mathrm{mg})$ gave salviaflaside ${ }^{19)}(2,9 \mathrm{mg})$, colorless amorphous solid, $[\alpha]_{\mathrm{D}}^{26}-10.4^{\circ}\left(\mathrm{H}_{2} \mathrm{O}\right.$, $c=0.05)$, and $\mathbf{1}(37 \mathrm{mg})$ by reversed-phase preparative TLC (RP-18 plate, $\mathrm{CH}_{3} \mathrm{CN}: \mathrm{H}_{2} \mathrm{O}=22: 78$ for the former and 27:73 for the latter).

Salvianolic Acid K (1) Colorless amorphous solid, $[\alpha]_{\mathrm{D}}^{26}+31.2^{\circ}$ $\left(\mathrm{H}_{2} \mathrm{O}, c=0.05\right)$. Negative ion FAB-MS $m / z$ : $555.1145[\mathrm{M}-\mathrm{H}]^{-}$ $\left(\mathrm{C}_{27} \mathrm{H}_{23} \mathrm{O}_{13}\right.$ requires 555.1139). UV $\lambda_{\max }(\mathrm{MeOH}) \mathrm{nm}(\log \varepsilon): 210$ (3.2), 220 (3.4), 230 (sh), $286(2.9), 323(2.4)$. IR $v_{\max }(\mathrm{KBr}) \mathrm{cm}^{-1}: 3400$, 1700, 1600, 1515, 1410. ${ }^{1} \mathrm{H}$ - and ${ }^{13} \mathrm{C}-\mathrm{NMR}$ : Table 3.

Methylation of Salvianolic Acid K (1) A mixture of $1(200 \mathrm{mg})$ and $\mathrm{K}_{2} \mathrm{CO}_{3}(1 \mathrm{~g})$ in dry acetone $(14 \mathrm{ml})$ was stirred for $5 \mathrm{~min}$ and $\left(\mathrm{CH}_{3}\right)_{2} \mathrm{SO}_{4}$ $(\mathrm{lml})$ was added. After stirring overnight at room temperature, the reaction mixture was filtered through silica gel column. The eluate was evaporated and separated by preparative TLC using $\mathrm{MeOH}-\mathrm{CHCl}_{3}$ (10:90) to give a heptamethylsalvianolic acid $\mathrm{K}(\mathbf{1 a}, 68 \mathrm{mg}) .{ }^{1} \mathrm{H}-\mathrm{NMR}{ }^{28)}$ $\left(\mathrm{CDCl}_{3}\right) \delta: 3.13\left(1 \mathrm{H}, \mathrm{dd}, J=14.5,8 \mathrm{~Hz}, 7^{\prime}-\mathrm{H}\right), 3.19(1 \mathrm{H}, \mathrm{dd}, J=14.5$, $\left.5 \mathrm{~Hz}, 7^{\prime}-\mathrm{H}\right), 3.70\left(3 \mathrm{H}, \mathrm{s}, 9^{\prime \prime}-\mathrm{OCH}_{3}\right), 3.75\left(3 \mathrm{H}, \mathrm{s}, 9^{\prime}-\mathrm{OCH}_{3}\right), 3.85(3 \mathrm{H}, \mathrm{s}$, $\left.3^{\prime}-\mathrm{OCH}_{3}\right), 3.86\left(3 \mathrm{H}, \mathrm{s}, 4^{\prime}-\mathrm{OCH}_{3}\right), 3.87\left(6 \mathrm{H}, \mathrm{s}, 3-\mathrm{OCH}_{3}, 4^{\prime \prime}-\mathrm{OCH}_{3}\right), 3.89$ $\left(3 \mathrm{H}, \mathrm{s}, 3^{\prime \prime}-\mathrm{OCH}_{3}\right), 4.79\left(1 \mathrm{H}, \mathrm{d}, J=5.5 \mathrm{~Hz}, 8^{\prime \prime}-\mathrm{H}\right), 5.16(1 \mathrm{H}, \mathrm{br}$ d, $\left.J=5.5 \mathrm{~Hz}, 7^{\prime \prime}-\mathrm{H}\right), 5.35\left(1 \mathrm{H}, \mathrm{dd}, J=8,5 \mathrm{~Hz}, 8^{\prime}-\mathrm{H}\right), 6.33(1 \mathrm{H}, \mathrm{d}, J=15.5 \mathrm{~Hz}$, $8-\mathrm{H}), 6.76-6.81\left(3 \mathrm{H}, \mathrm{m}, 2^{\prime}-\mathrm{H}, 5^{\prime}-\mathrm{H}, 6^{\prime}-\mathrm{H}\right), 6.80(1 \mathrm{H}, \mathrm{d}, J=8 \mathrm{~Hz}, 5-\mathrm{H})$, $6.84\left(1 \mathrm{H}, \mathrm{d}, J=8 \mathrm{~Hz}, 5^{\prime \prime}-\mathrm{H}\right), 6.98\left(1 \mathrm{H}, \mathrm{dd}, J=8,2 \mathrm{~Hz}, 6^{\prime \prime}-\mathrm{H}\right), 7.00(1 \mathrm{H}$, $\mathrm{dd}, J=8,2 \mathrm{~Hz}, 6-\mathrm{H}), 7.02(1 \mathrm{H}, \mathrm{d}, J=2 \mathrm{~Hz}, 2-\mathrm{H}), 7.05(1 \mathrm{H}, \mathrm{d}, J=2 \mathrm{~Hz}$, $\left.2^{\prime \prime}-\mathrm{H}\right), 7.60(1 \mathrm{H}, \mathrm{d}, J=15.5 \mathrm{~Hz}, 7-\mathrm{H})$. Positive ion DCI-MS $m / z: 655.2396$ $[\mathrm{M}+\mathrm{H}]^{+}\left(\mathrm{C}_{34} \mathrm{H}_{39} \mathrm{O}_{13}\right.$ requires 655.2391$), 637.2282\left[\mathrm{M}+\mathrm{H}-\mathrm{H}_{2} \mathrm{O}\right]^{+}$ (637.2285).

DIBAH Reduction of Heptamethylsalvianolic Acid K (1a) To a stirred solution of $1 \mathbf{a}(40.0 \mathrm{mg})$ in dry THF ( $3 \mathrm{ml})$, DIBAH (1 m hexane solution, $1 \mathrm{ml}$ ) was added at $-70^{\circ} \mathrm{C}$ under $\mathrm{Ar}$ and the stirring was continued for $2 \mathrm{~h}$. To the reaction mixture $\mathrm{MeOH}(10 \mathrm{ml})$ was added and the whole was stirred for an additional $30 \mathrm{~min}$. After filtration through a Celite pad the filtrate was concentrated and subjected to preparative TLC with $10 \% \mathrm{MeOH}-\mathrm{CHCl}_{3}$ to give a triol $13(15.0 \mathrm{mg})$; colorless amorphous solid; ${ }^{1} \mathrm{H}-\mathrm{NMR}\left(\mathrm{CDCl}_{3}\right) \delta: 3.69\left(1 \mathrm{H}, \mathrm{dd}, J=12,3.5 \mathrm{~Hz}, 9^{\prime \prime}-\mathrm{H}\right), 3.870$, $3.875,3.880\left(\right.$ each $\left.3 \mathrm{H}, \mathrm{s}, 3-\mathrm{OCH}_{3}, 3^{\prime \prime}-\mathrm{OCH}_{3}, 4^{\prime \prime}-\mathrm{OCH}_{3}\right), 3.91(1 \mathrm{H}$, dd, $\left.J=12,5.5 \mathrm{~Hz}, 9^{\prime \prime}-\mathrm{H}\right), 4.17\left(1 \mathrm{H}, \mathrm{td}, J=5.5,3.5 \mathrm{~Hz}, 8^{\prime \prime}-\mathrm{H}\right), 4.3 \mathrm{l}(2 \mathrm{H}, \mathrm{brd}$, $\left.J=5.5 \mathrm{~Hz}, 9-\mathrm{H}_{2}\right), 4.98\left(1 \mathrm{H}, \mathrm{d}, J=4.5 \mathrm{~Hz}, 7^{\prime \prime}-\mathrm{H}\right), 6.27(1 \mathrm{H}, \mathrm{dt}, J=16$, $5.5 \mathrm{~Hz}, 8-\mathrm{H}), 6.54(1 \mathrm{H}, \mathrm{brd}, J=16 \mathrm{~Hz}, 7-\mathrm{H}), 6.84,6.87$ (each $1 \mathrm{H}, \mathrm{d}$, $\left.J=8 \mathrm{~Hz}, 5-\mathrm{H}, 5^{\prime \prime}-\mathrm{H}\right), 6.90,6.91$ (each $1 \mathrm{H}, \mathrm{dd}, J=8,1.5 \mathrm{~Hz}, 6-\mathrm{H}, 6^{\prime \prime}-\mathrm{H}$ ), 6.94, 6.97 (each 1H, d, $J=1.5 \mathrm{~Hz}, 2-\mathrm{H}, 2^{\prime \prime}-\mathrm{H}$ ).

MTPA Esters of Heptamethylsalvianolic Acid K (1a) To a stirred solution of $1 \mathrm{a}(18.5 \mathrm{mg})$ in $\mathrm{CCl}_{4}(1.5 \mathrm{ml})$ and pyridine $(1.5 \mathrm{ml})$, $R$-(+)-MTPA chloride or $S$-(-)-MTPA chloride $(20 \mu \mathrm{l})$ was added. The mixture was stirred overnight at room temperature and subjected to preparative TLC with $\mathrm{MeOH}-\mathrm{CHCl}_{3}(5: 95)$ to afford the $R$-MTPA ester $(\mathbf{1 b}, 17.0 \mathrm{mg})$ or $S$-MTPA ester $(\mathbf{1 c}, 17.0 \mathrm{mg})$.

$R$-MTPA Ester (1b): Colorless amorphous solid. Positive ion DCI-MS $m / z: 871.2790[\mathrm{M}+\mathrm{H}]^{+}\left(\mathrm{C}_{44} \mathrm{H}_{46} \mathrm{O}_{15} \mathrm{~F}_{3}\right.$ requires 871.2789). ${ }^{1} \mathrm{H}-\mathrm{NMR}^{28)}$ $\left(\mathrm{CDCl}_{3}, 25^{\circ} \mathrm{C}\right) \delta: 3.13\left(1 \mathrm{H}, \mathrm{dd}, J=14.5,8 \mathrm{~Hz}, 7^{\prime}-\mathrm{H}\right), 3.19(1 \mathrm{H}, \mathrm{dd}$, $\left.J=14.5,5 \mathrm{~Hz}, 7^{\prime}-\mathrm{H}\right), 3.51\left(3 \mathrm{H}\right.$, br s, $\mathrm{OCH}_{3}$ in MTPA), $3.67(3 \mathrm{H}, \mathrm{s}$, $\left.9^{\prime \prime}-\mathrm{OCH}_{3}\right), 3.741\left(3 \mathrm{H}, \mathrm{s}, 9^{\prime}-\mathrm{OCH}_{3}\right), 3.743\left(3 \mathrm{H}, \mathrm{s}, 3^{\prime \prime}-\mathrm{OCH}_{3}\right), 3.76(3 \mathrm{H}$, s, $\left.3-\mathrm{OCH}_{3}\right), 3.850\left(3 \mathrm{H}, \mathrm{s}, 3^{\prime} \mathrm{OCH}_{3}\right), 3.853\left(3 \mathrm{H}, \mathrm{s}, 4^{\prime}-\mathrm{OCH}_{3}\right), 3.88(3 \mathrm{H}$, s, $\left.4^{\prime \prime}-\mathrm{OCH}_{3}\right), 5.01\left(1 \mathrm{H}, \mathrm{d}, J=5.5 \mathrm{~Hz}, 8^{\prime \prime}-\mathrm{H}\right), 5.36(1 \mathrm{H}, \mathrm{dd}, J=8,5 \mathrm{~Hz}$, $\left.8^{\prime}-\mathrm{H}\right), 6.32(1 \mathrm{H}, \mathrm{d}, J=16 \mathrm{~Hz}, 8-\mathrm{H}), 6.38\left(1 \mathrm{H}, \mathrm{d}, J=5.5 \mathrm{~Hz}, 7^{\prime \prime}-\mathrm{H}\right), 6.68$ $(1 \mathrm{H}, \mathrm{d}, J=8 \mathrm{~Hz}, 5-\mathrm{H}), 6.76-6.82\left(3 \mathrm{H}, \mathrm{m}, 2^{\prime}-\mathrm{H}, 5^{\prime}-\mathrm{H}, 6^{\prime}-\mathrm{H}\right), 6.80(1 \mathrm{H}$, d, $\left.J=8 \mathrm{~Hz}, 5^{\prime \prime}-\mathrm{H}\right), 6.89-6.93\left(2 \mathrm{H}, \mathrm{m}, 2^{\prime \prime}-\mathrm{H}, 6^{\prime \prime}-\mathrm{H}\right), 6.96(1 \mathrm{H}, \mathrm{dd}, J=8$, $2 \mathrm{~Hz}, 6-\mathrm{H}), 6.99(1 \mathrm{H}, \mathrm{d}, J=2 \mathrm{~Hz}, 2-\mathrm{H}), 7.27(2 \mathrm{H}, \mathrm{tt}, J=7.5,1.5 \mathrm{~Hz}, \mathrm{Ph})$, $7.31(1 \mathrm{H}, \mathrm{tt}, J=7.5,1.5 \mathrm{~Hz}, \mathrm{Ph}), 7.4 \mathrm{l}(2 \mathrm{H}$, br d, $J=7.5 \mathrm{~Hz}, \mathrm{Ph}), 7.60$ $(1 \mathrm{H}, \mathrm{d}, J=16 \mathrm{~Hz}, 7-\mathrm{H})$.

$S$-MTPA Ester (1c): Colorless amorphous solid. Positive ion DCI-MS $m / z: 871.2776[\mathrm{M}+\mathrm{H}]^{+}\left(\mathrm{C}_{44} \mathrm{H}_{46} \mathrm{O}_{15} \mathrm{~F}_{3}\right.$ requires 871.2789). ${ }^{1} \mathrm{H}-\mathrm{NMR}^{28)}$ $\left(\mathrm{CDCl}_{3}, 25^{\circ} \mathrm{C}\right) \delta: 3.12\left(1 \mathrm{H}, \mathrm{dd}, J=14,8 \mathrm{~Hz}, 7^{\prime}-\mathrm{H}\right), 3.19(1 \mathrm{H}, \mathrm{dd}, J=14$ $\left.5 \mathrm{~Hz}, 7^{\prime}-\mathrm{H}\right), 3.44\left(3 \mathrm{H}\right.$, brs, $\mathrm{OCH}_{3}$ in MTPA), $3.61\left(3 \mathrm{H}, \mathrm{s}, 9^{\prime \prime}-\mathrm{OCH}_{3}\right)$, $3.73\left(3 \mathrm{H}, \mathrm{s}, 3-\mathrm{OCH}_{3}\right), 3.74\left(3 \mathrm{H}, \mathrm{s}, 9^{\prime}-\mathrm{OCH}_{3}\right), 3.84\left(6 \mathrm{H}, \mathrm{s}, 3^{\prime}-\mathrm{OCH}_{3}\right.$,
$\left.4^{\prime}-\mathrm{OCH}_{3}\right), 3.85\left(3 \mathrm{H}, \mathrm{s}, 3^{\prime \prime}-\mathrm{OCH}_{3}\right), 3.89\left(3 \mathrm{H}, \mathrm{s}, 4^{\prime \prime}-\mathrm{OCH}_{3}\right), 4.99(1 \mathrm{H}, \mathrm{d}$, $\left.J=6 \mathrm{~Hz}, 8^{\prime \prime}-\mathrm{H}\right), 5.35\left(1 \mathrm{H}, \mathrm{dd}, J=8,5 \mathrm{~Hz}, 8^{\prime}-\mathrm{H}\right), 6.30(1 \mathrm{H}, \mathrm{d}, J=16 \mathrm{~Hz}$, $8-\mathrm{H}), 6.37\left(1 \mathrm{H}, \mathrm{d}, J=6 \mathrm{~Hz}, 7^{\prime \prime}-\mathrm{H}\right), 6.62(1 \mathrm{H}, \mathrm{d}, J=8 \mathrm{~Hz}, 5-\mathrm{H}), 6.76-6.81$ $\left(3 \mathrm{H}, \mathrm{m}, 2^{\prime}-\mathrm{H}, 5^{\prime}-\mathrm{H}, 6^{\prime}-\mathrm{H}\right), 6.84\left(1 \mathrm{H}, \mathrm{d}, J=8 \mathrm{~Hz}, 5^{\prime \prime}-\mathrm{H}\right), 6.92(1 \mathrm{H}, \mathrm{dd}$, $J=8,2 \mathrm{~Hz}, 6-\mathrm{H}), 6.94(1 \mathrm{H}, \mathrm{d}, J=2 \mathrm{~Hz}, 2-\mathrm{H}), 7.03(1 \mathrm{H}, \mathrm{dd}, J=8,2 \mathrm{~Hz}$, $\left.6^{\prime \prime}-\mathrm{H}\right), 7.10\left(1 \mathrm{H}, \mathrm{d}, J=2 \mathrm{~Hz}, 2^{\prime \prime}-\mathrm{H}\right), 7.28(2 \mathrm{H}, \mathrm{tt}, J=7.5,1.5 \mathrm{~Hz}, \mathrm{Ph})$, $7.34(1 \mathrm{H}, \mathrm{tt}, J=7.5,1.5 \mathrm{~Hz}, \mathrm{Ph}), 7.38(2 \mathrm{H}, \mathrm{brd}, J=7.5 \mathrm{~Hz}, \mathrm{Ph}), 7.58$ $(1 \mathrm{H}, \mathrm{d}, J=16 \mathrm{~Hz}, 7-\mathrm{H})$.

Methanolysis of Heptamethylsalvianolic Acid K (1a) To a solution of 1a $(50 \mathrm{mg})$ in dry $\mathrm{MeOH}(5 \mathrm{ml})$, a solution of $\mathrm{NaOMe}$ in $\mathrm{MeOH}(1 \mathrm{~N}$, $5 \mathrm{ml}$ ) was added. After $2 \mathrm{~h}$ reaction, the solution was subjected to preparative TLC with AcOEt-hexane $(50: 50)$ to give methyl $3-(3,4-$ dimethoxyphenyl)-( $R$ )-propionate ${ }^{25)}(14,5.5 \mathrm{mg})$, methyl 4- $O-[(1 S, 2 R)$ 2-hydroxy-1-methoxycarbonyl-2-(3,4-dimethoxyphenyl)ethyl]ferulate $(15,14.0 \mathrm{mg}), 3,4$-dimethoxybenzaldehyde $(16,1.0 \mathrm{mg})$, and methyl 4- $O$-(methoxycarbonylmethyl)ferulate $(\mathbf{1 7}, 1.5 \mathrm{mg}$ ).

Methyl 3-(3,4-Dimethoxyphenyl)-( $R$ )-propionate (14): Colorless amorphous solid, $[\alpha]_{\mathrm{D}}^{26}-4.8^{\circ}(c=0.08, \mathrm{MeOH})$. EI-MS $m / z: 240\left(\mathrm{M}^{+}\right)$. ${ }^{1} \mathrm{H}-\mathrm{NMR}^{28)}\left(\mathrm{CDCl}_{3}\right) \delta: 2.70\left(1 \mathrm{H}\right.$, br d, $\left.J=5.5 \mathrm{~Hz}, 8^{\prime}-\mathrm{OH}\right), 2.92(1 \mathrm{H}, \mathrm{dd}$, $\left.J=14,6.5 \mathrm{~Hz}, 7^{\prime}-\mathrm{H}\right), 3.08\left(1 \mathrm{H}, \mathrm{dd}, J=14,4.5 \mathrm{~Hz}, 7^{\prime}-\mathrm{H}\right), 3.78(3 \mathrm{H}, \mathrm{s}$, $\left.9^{\prime}-\mathrm{OCH}_{3}\right), 3.86,3.87$ (each $\left.3 \mathrm{H}, \mathrm{s}, 3^{\prime}-\mathrm{OCH}_{3}, 4^{\prime}-\mathrm{OCH}_{3}\right), 4.44(1 \mathrm{H}$, br ddd, $\left.J=6.5,5.5,4.5 \mathrm{~Hz}, 8^{\prime}-\mathrm{H}\right), 6.73-6.77\left(2 \mathrm{H}, \mathrm{m}, 2^{\prime}-\mathrm{H}, 6^{\prime}-\mathrm{H}\right), 6.81(1 \mathrm{H}, \mathrm{d}$, $\left.J=8.5 \mathrm{~Hz}, 5^{\prime}-\mathrm{H}\right)$.

Methyl 4-O-[(1S,2R)-2-Hydroxy-1-methoxycarbonyl-2-(3,4-dimethoxyphenyl)ethyl]ferulate (15): Colorless amorphous solid, $[\alpha]_{\mathrm{D}}^{26}-6.7^{\circ}$ $\left(c=0.15, \mathrm{CHCl}_{3}\right)$. Positive ion DCI-MS $m / z: 447.1667[\mathrm{M}+\mathrm{H}]^{+}$ $\left(\mathrm{C}_{23} \mathrm{H}_{27} \mathrm{O}_{9}\right.$ requires 447.1655), $429.1548\left[\mathrm{M}+\mathrm{H}-\mathrm{H}_{2} \mathrm{O}\right]^{+}\left(\mathrm{C}_{23} \mathrm{H}_{25} \mathrm{O}_{8}\right.$ requires 429.1549$) .{ }^{1} \mathrm{H}-\mathrm{NMR}^{28)}\left(\mathrm{CDCl}_{3}\right) \delta: 3.70,3.80,3.88,3.89,3.90$ (each $\left.3 \mathrm{H}, \mathrm{s}, 5 \times \mathrm{OCH}_{3}\right), 4.80\left(1 \mathrm{H}, \mathrm{d}, J=5 \mathrm{~Hz}, 8^{\prime \prime}-\mathrm{H}\right), 5.17(1 \mathrm{H}, \mathrm{brd}$, $\left.J=5 \mathrm{~Hz}, 7^{\prime \prime}-\mathrm{H}\right), 6.32(1 \mathrm{H}, \mathrm{d}, J=16 \mathrm{~Hz}, 8-\mathrm{H}), 6.81,6.85($ each $1 \mathrm{H}, \mathrm{d}$, $\left.J=8 \mathrm{~Hz}, 5-\mathrm{H}, 5^{\prime \prime}-\mathrm{H}\right), 6.99,7.02$ (each $\left.1 \mathrm{H}, \mathrm{dd}, J=8,2 \mathrm{~Hz}, 6-\mathrm{H}, 6^{\prime \prime}-\mathrm{H}\right)$, $7.04,7.05$ (each $\left.1 \mathrm{H}, \mathrm{d}, J=2 \mathrm{~Hz}, 2-\mathrm{H}, 2^{\prime \prime}-\mathrm{H}\right), 7.60(1 \mathrm{H}, \mathrm{d}, J=16 \mathrm{~Hz}, 7-\mathrm{H})$.

3,4-Dimethoxybenzaldehyde (16): Colorless amorphous solid. EI-MS $m / z: 166\left(\mathrm{M}^{+}\right) .{ }^{1} \mathrm{H}-\mathrm{NMR}^{28)}\left(\mathrm{CDCl}_{3}\right) \delta: 3.96,3.99\left(\right.$ each $3 \mathrm{H}, \mathrm{s}, 3^{\prime \prime}-\mathrm{OCH}_{3}$, $\left.4^{\prime \prime}-\mathrm{OCH}_{3}\right), 6.99\left(1 \mathrm{H}, \mathrm{d}, J=8 \mathrm{~Hz}, 5^{\prime \prime}-\mathrm{H}\right), 7.42\left(1 \mathrm{H}, \mathrm{d}, J=2 \mathrm{~Hz}, 2^{\prime \prime}-\mathrm{H}\right)$, $7.47\left(1 \mathrm{H}, \mathrm{dd}, J=8,2 \mathrm{~Hz}, 6^{\prime \prime}-\mathrm{H}\right), 9.86(1 \mathrm{H}, \mathrm{s}, \mathrm{CHO})$.

Methyl 4-O-(Methoxycarbonylmethyl)ferulate (17): Colorless amorphous solid. ${ }^{1} \mathrm{H}-\mathrm{NMR}\left(\mathrm{CDCl}_{3}\right) \delta: 3.81\left(6 \mathrm{H}, \mathrm{s}, 2 \times \mathrm{CO}_{2} \mathrm{CH}_{3}\right), 3.93(3 \mathrm{H}$, $\left.\mathrm{s}, 3-\mathrm{OCH}_{3}\right), 4.74\left(2 \mathrm{H}, \mathrm{s}, 8^{\prime \prime}-\mathrm{H}_{2}\right), 6.33(1 \mathrm{H}, \mathrm{d}, J=16 \mathrm{~Hz}, 8-\mathrm{H}), 6.79(1 \mathrm{H}$, $\mathrm{d}, J=9 \mathrm{~Hz}, 5-\mathrm{H}), 7.05-7.09(2 \mathrm{H}, \mathrm{m}, 2-\mathrm{H}, 6-\mathrm{H}), 7.63(1 \mathrm{H}, \mathrm{d}, J=16 \mathrm{~Hz}$, 7-H).

Acknowledgment The authors are grateful to Alps Pharmaceutical Co., Ltd, Furukawa, Japan for the kind gift of the raw material of $S$. deserta and to Dr. K. Komatsu and Dr. S. Yamaji of their institute for valuable information on Danshen and Xinjiang-Danshen.

\section{References and Notes}

1) Konta F., Shimizu T., "Flowering Plants and Ferns of the Tianshan Mountains in China," Tombow Publisher, Osaka, 1996, p. 110, 195; Borisova A. G., Volkova E. V., Gorshkova S. G., Klokov M. V., Knorring O. E., Kupriyanova L. A., Pobedimova E. G., Poyarkova A. I., Yuzepchuk S. V., "Flora of the U.S.S.R.," Shishkin B. K., ed., Vol. 21, Koeltz Scientific Books, Koenigstein, 1987, pp. 248-249; Botanical Institute of Yunnan, Nanjing College of Pharmacy, ed., "Flora Reipublicae Popularis Sinicae," Vol. 66, Science Press, Beijing, p. 161, 166, 168.

2) Pharmacopoeia Committee of the Health Ministry of the People's Republic of China, ed., "Pharmacopoeia of People's Republic of China," Vol. 1, Guangdong Scientific Technologic Publisher, Guangdong, 1995, pp. 62-63; Namba T., "The Encyclopedia of Wakan-Yaku (Traditional Sino-Japanese Medicines) with Color Pictures," Vol. I, Hoikusha Publishing Co., Ltd., Osaka, 1993, pp. 24-25; Chiang Su New Medicinal College, ed., "Dictionary of Chinese Crude Drugs," Shanghai Scientific Technologic Publisher, Shanghai, 1977, pp. 478-482.

3) Komatsu K., Sato T., Li X. B., Yamaji S., Namba T., Abstracts of Papers, The 117th Annual Meeting of the Pharmaceutical Society of Japan, Tokyo, March 1997, Part 2, p. 119.

4) Lin H.-C., Chang W.-L., Wu P.-L., Wu T.-S., J. Chin. Chem. Soc., 43, $199-201$ (1997); Ryu S. Y., No Z., Kim S. H., Ahn J. W., Planta Med., 63, $44-46$ (1997); Kuo Y. H., Wu C. H., J. Nat. Prod., 59, 625-628 (1996); Zhao B. L., Jiang W., Zhao Y., Hou J. W., Xin W. J., Biochem. Mol. Biol. Int., 38, 1171-1182 (1996); 
Liu J., Zapp J., Becker H., Planta Med., 61, 453-455 (1995); Ling M., Liao L. B., Xu Y. H., Xi Q. L., Qian Y., Ge B. X., Experimental and Cinical Immunogenetics, 10, 45-49 (1993); Fung K. P., Zeng L. H., Wu J., Wong H. N. C., Lee C. M., Hon P. M., Chang H. M., Wu T. W., Life Sci., 52, PL239-PL244 (1993); Okamura N., Sato M., Yagi A., Tanonaka K., Takeo S., Planta Med., 58, 571-572 (1992); Liu G. T., Zhang T. M., Wang B. E., Wang Y. W., Biochem. Pharmacol., 43, 147-152 (1992).

5) Zhang B., Liu L., Zhongcaoyao, 27, 634-636 (1996); Kong D., Zhongguo Yiyao Gongye Zazhi, 20, 279-285 (1989); Zheng G., Kakisawa H., Zhongguo Yaoxue Zazhi, 24, 6-10 (1989); Tang W., Eisenbrand G., "Chinese Drugs of Plant Origin," Springer-Verlag, Berlin, 1992, pp. 891-902; see also the references cited therein.

6) Tezuka Y., Kasimu R., Basnet P., Namba T., Kadota S., Chem. Pharm. Bull., 45, 1306-1311 (1997); Kasimu R., Basnet P., Tezuka Y., Kadota S., Namba T., ibid., 45, 564-566 (1997).

7) Hase K., Kasimu R., Basnet P., Kadota S., Namba T., Planta Med., 63, 22-26 (1997).

8) Savona G., Bruno M., Rodríguez B., Marco J. L., Phytochemistry, 26, 3305-3308 (1987)

9) "Royleanones" are characterized by $p$-benzoquinoid C-ring within abietane skeleton, while "tanshinones" are by $o$ - or $p$ naphthoquinone group within nor- or bisnor-abietane skeleton.

10) von Patudin A., Romanowa A., Sokolow W. S., Pribylowa G., Planta Med., 26, 201-207 (1974).

11) Romanova A. S., Pribylova G. F., Patudin A. V., Leskova E. S., Pakaln D. A., Ban'kovskii A. I., Khim. Prirodn. Soedin., 1972, 237 [Chem. Nat. Prod., 1971, 231-232].

12) Hensch M., Rüedi P., Eugster C. H., Helv. Chim. Acta, 58, 1921-1934 (1975)

13) Rüedi P., Helv. Chim. Acta, 67, 1116-1120 (1984).

14) Danheiser R. L., Casebier D. S., Firooznia F., J. Org. Chem., 60,
$8341-8350$ (1995).

15) Sabri N. N., Abou-Donia A. A., Assad A. M., Ghazy N. M., El-Lakany A. M., Tempesta M. S., Sanson D. R., Planta Medica, 55, 582 (1989); Kupchan S. M., Karim A., Marcks C., J. Am. Chem. Soc., 90, 5923-5924 (1968).

16) Matsumoto T., Usui S., Bull. Chem. Soc. Jpn., 52, 212-215(1979).

17) Jonathan L. T., Che C.-T., Pezzuto J. M., Fong H. H. S., Farnsworth N. R., J. Nat. Prod., 52, 571-575 (1989).

18) Basnet P., Kadota S., Terashima S., Shimizu M., Namba T., Chem. Pharm. Bull., 41, 1238-1243 (1993).

19) Zhao L. M., He W. L., Liang X. T., Li L. N., Chin. Chem. Lett., 7, 449-452 (1996).

20) Kelley C. J., Mahajan J. R., Brooks L. C., Neubert L. A., Breneman W. R., Carmack M., J. Org. Chem., 12, 1804-1815 (1975); Kelley C. J., Harruff R. C., Carmack M., ibid., 41, 449-455 (1976).

21) Tanaka T., Morimoto S., Nonaka G., Nishioka I., Yokozawa T., Chung H. Y., Oura H., Chem. Pharm. Bull., 37, 340-344 (1989).

22) Hattori M., Hada S., Shu Y.-Z., Kakiuchi N., Namba T., Chem. Pharm. Bull., 35, 668-674 (1987).

23) Braga A. C. H., Zacchino S., Badano H., Sierra M. G., Rveda E. A., Phytochemistry, 23, 2025-2028 (1984).

24) Matsuda N., Kikuchi M., Chem. Pharm. Bull., 44, 1676-1679 (1996).

25) Dale J. A., Mosher H. S., J. Am. Chem. Soc., 95, 512-519(1973).

26) Ohtani I., Kusumi T., Kashman Y., Kakisawa H., J. Am. Chem. Soc., 113, 4092-4096 (1991).

27) Chrzanowska M., J. Nat. Prod., 58, 401-407 (1995); Yahara S., Satoshiro M., Nishioka I., Nagasawa T., Oura H., Chem. Pharm. Bull., 33, 527-531 (1985).

28) The same numbering as used for 1 was used in these ${ }^{1} \mathrm{H}$-NMR assignments which were done by ${ }^{1} \mathrm{H}^{-1} \mathrm{H}$ COSY and difference NOE experiments. 